\title{
Note
}

\section{Effect of Addition of Alcohols on Gelation of Polyvinyl Alcohol Aqueous Solution by $r$-Ray Irradiation}

\author{
Hisatake NARASAKI \\ Department of Chemistry, Faculty of Science, Saitama University \\ Shimo-Okubo, Urawa-shi, Saitama 338 \\ Received October 6, 1978
}

Key Words: cobalt-60, $\gamma$-ray, polyvinyl alcohol, gelation, alcohol, iodine, spectrophotometry

\section{Introduction}

Previously the author reported the effect of inorganic acids or bases on gelation of aqueous solution of polyvinyl alcohol (PVA) ${ }^{1)}$. Below the critical concentration, the effect was investigated by color development with iodine after $\gamma$-ray irradiation. In the present study the effect of several alcohols on the gelation was investigated. Methanol, ethanol, isopropyl alcohol, cyclohexanol and phenol were used as additıves.

\section{Experimental}

The procedures of the preparation of sample solutions and irradiation were the same as described previously ${ }^{1)}$. The viscometric degree of polymerization of PVA was 1790.

\section{Results and discussion}

The ratios of the absorbances of the PVAiodine complex of the irradiated samples to those of unirradiated were plotted against the absorbed dose and were referred to as the relative absorbance in Figs. 1-3. Figure 1 shows the effect of the concentration of methanol on the absorbance. The absorbances decrease with a decrease in concentration. Similar results were obtained with ethanol and isopropyl alcohol. $\mathrm{H}$ and $\mathrm{OH}$ radicals produced by radiolysis of

†ポリビニルアルコール水溶液の $\gamma$ 線照射によるゲ ル化に対するフルコールの効果. 楢崎久武：埼玉 大学理学部化学教室, 338埼玉県浦和市下大久保 255 water predominantly abstract $\alpha$-hydrogen of aliphatic alcuhols.

$$
\begin{aligned}
& \mathrm{R}_{2} \mathrm{CHOH}+\mathrm{H} \cdot \longrightarrow \mathrm{R}_{2} \dot{\mathrm{C} O H}+\mathrm{H}_{2} \\
& \mathrm{R}_{2} \mathrm{CHOH}+\cdot \mathrm{OH} \longrightarrow \mathrm{R}_{2} \dot{\mathrm{COH}}+\mathrm{H}_{2} \mathrm{O}
\end{aligned}
$$

where $\mathrm{R}$ is $\mathrm{H}$ and/or $\mathrm{CH}_{3}$. Reaction 2 is known to play a major role in the dehydrogenation ${ }^{2}$. Therefore the protection of PVA is considered to be done mainly by the reaction of $\mathrm{OH}$ radicals with these alcohols.

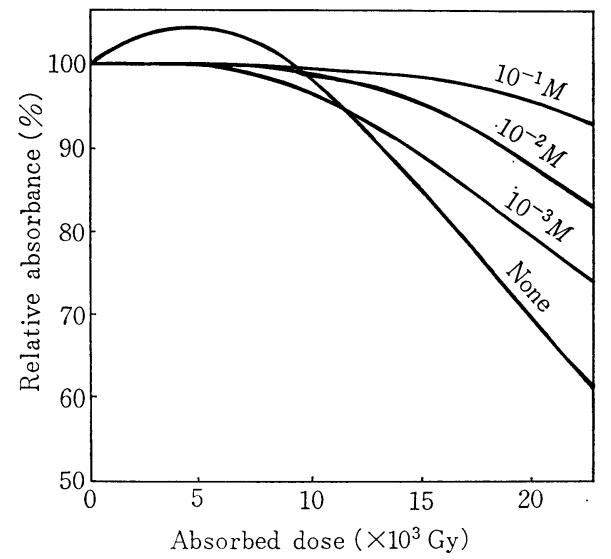

Fig. 1 Effect of the concentration of methanol on the relative absorbance. The concentration of polyvinyl alcohol is $0.1 \%$ (w/v).

Figure 2 shows the effect of concentration of phenol on the absorbance. In this instance the absorbances are little affected by concentration. Similar results were obtained with cyclohexanol. Hydroxyl radicals have high electro- 
philic nature on and high reactivity toward aromatic compounds ${ }^{3)}$.

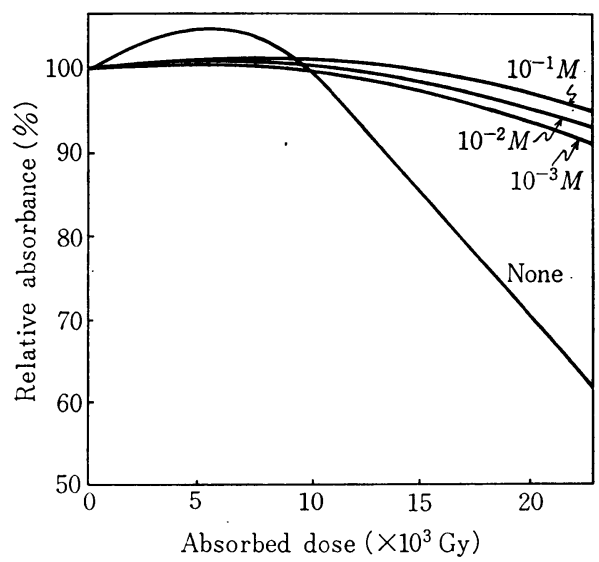

Fig. 2 Effect of the concentration of phenol on the relative absorbance. The concentration of polyvinyl alcohol is $0.1 \%$ (w/v).

Figure 3 shows the effect of the addition of different alcohols on the absorbance. The typical rate constants of $\mathrm{OH}$ radicals with methanol, ethanol, isopropyl alcohol and phenol are $8.8 \times$ $10^{8}, 1.8 \times 10^{9}, 2.0 \times 10^{9}$ and $1.8 \times 10^{10} \mathrm{dm}^{3} \mathrm{~mol}^{-1}$ $\mathrm{s}^{-1}$, respectively ${ }^{4}$. The extent of protection by the addition of these alcohols increases in the above order. While the rate constant with cyclohexanol is not found in the literature, cyclohexanol produces mainly $\alpha$-hydroxycyclohexyl radical ${ }^{5}$. In addition, the $\gamma$ - and $\delta$-radicals are formed in a small fraction. It seems reasonable that the extent of protection by such a alicyclic compound is situated between those by aliphatic and aromatic compouds.

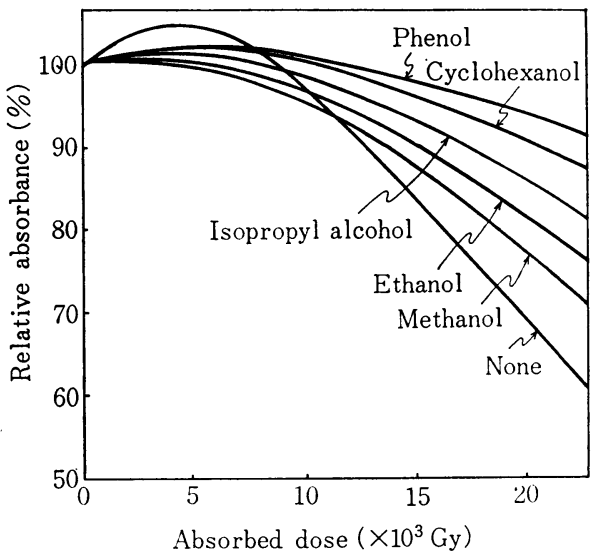

Fig. 3 Effect of different alcohols on the relative absorbance. The concentrations of polyvinyl alcohol and the alcohols are $0.1 \%$ (w/v) and $10^{-3} M$, respectively.

\section{Acknowledgment}

The author wishes to thank Mr. K. Hinatsu for his technical assistance throughout this study.

\section{References}

1) H. Narasaki: Radioisotopes, 27, 568(1978)

2) M. Simic, P. Neta and E. Hayon: $J$. Phys. Chem., 73, 3794 (1969)

3) M. Anbar, D. Meyerstein and P. Neta: ibid., 70, 2660 (1966)

4) G.E. Adams, J.W. Boag, J. Currant and B.D. Michael: "Pulse Radiolysis", p. 131, Academic Press, New York (1965)

5) T. Shiga, A. Boukhors and P. Douzou: J. Phys. Chem., 71, 4264 (1967) 